\title{
Religiosity and Preventing Risky Behaviors
}

\author{
Azizollah Mojahed ${ }^{1, *}$ \\ ${ }^{1}$ Department of Clinical Psychology, Zahedan University of Medical Sciences, Zahedan, IR Iran \\ ${ }^{*}$ Corresponding author: Azizollah Mojahed, Department of Clinical Psychology, Zahedan University of Medical Sciences, Zahedan, IR Iran. Tel: +98-5414522636, Fax: +98-5414522636, \\ E-mail:aziz_mojahed@yahoo.com
}

Received: August 17, 2014; Accepted: August 18, 2014

Keywords: Risk-Taking; Religion

There is a consensus among psychological theorists indicating that beliefs and behaviors are related. Since most of the homogeneous and institutionalized tenets among social groups and people, religious beliefs relation with behaviors is a theme deserved to be studied. Examining the relation between religious beliefs and risky behaviors will help to predict and prevent such behaviors. Most psychiatrists and psychologists working in religious-social environments may hear repeated sentences from their stressful clients every day such as: "I would put an end to my life to stop all these sufferings, if I were allowed by religion or if the afterlife and the hell did not exist;" or "I would have already done something (bad) to myself if I didn't fear God."

In the recent decade many studies uncovered the negative relationship between adherence to the religious beliefs and showing certain behaviors such as suicide $(1,2)$, drug abuse (3-5), alcoholism (4,5), violence (6), and risky sexual behaviors $(4,7,8)$. The positive relationship between religiosity and mental health is demonstrated in some studies, such as that of Ronneberg, (9), while others assume religion as the balancing factor in causal relation of other variables with risky behaviors. For example, the level of religiosity was considered as a balancing factor in a study on the relationship between depression and suicide (10). A limited number of studies have also dealt with the mechanisms by which religion influences delinquent behaviors. The approach used by some studies was to separate internal and external religions (11), while the others considered religion in two categories: personal and social (5).

The survey tools were mostly the questionnaires filled either by patients or their relatives. The questionnaires have covered different dimensions such as importance of religion, adherence to religious rites and customs, and/ or participation in religious services. It has been tried to study various communities including those of Muslims, Christians, and Jews living in various parts of the world (12). Relying on religious doctrines, several intervention- al studies have also been conducted aiming to improve the religious attitudes to influence the mental health in stressful people (13).

Regarding the reviewed meta-analyses and findings it can be concluded that analysis of the role religion plays in emergence of risky behaviors is a broad and multifunctional field where the researchers are still at its very beginning. In fact, religion includes a broad range of forms from internal religion to external and flashy religion, which are sometimes used as a tool to achieve certain goals; from worshiping idols and the dead people to monotheist religions; from religions limited to individual ethics, limited rites, or Monasticism to religions meddled in all sorts of human life; from the recognized and official religions in communities to religious beliefs related to limited and sometimes clandestine and forbidden groups. Sometimes a religion has several sects and branches and their followers enjoy various levels of assumptions, imperatives and adherences.

Aside from those religious beliefs and rites that are clearly dangerous and balancing them is a human prophecy, the observations and concluding the limited research findings indicate that the religious people enjoy a higher mental and behavioral hygiene rather than the irreligious people in a given community. Analyzing religious people and religious texts, here focus is on the Islamic texts, to indicate the impact of religion on decreasing risky behaviors, a theoretical conclusion is proposed: Religion may decrease risky behaviors both directly and indirectly. The direct way includes setting orders and prohibitions. Orders enforce the followers to practice healthy and riskless behaviors, to serve themselves and the others, to observe peace and humanitarianism and to meet the needs of the people in need. Prohibitions prevent people from doing risky behaviors, for example to avoid playing with dangerous and killing tools, consuming alcoholic drinks and drugs, and violating the others' rights, which is a source of stress, harming the theirs and the others' body, and limiting sexual behav-

Copyright @ 2014, Zahedan University of Medical Sciences; Published by Kowsar Corp. This is an open-access article distributed under the terms of the Creative Commons Attribution License, which permits unrestricted use, distribution, and reproduction in any medium, provided the original work is properly cited. 
ior etc. for the indirect process religion limits the proper condition for doing risky behaviors through different ways. Membership in religious communities is a way either to meet the need of belonging to a group, or to find social support, which in turn mitigates stress, improves the mental health (such as Rajaee (14)), and decreases risky behaviors potential in people. Religion contributes to the development of identity and stability in people (14). Identity instability, that its clinical sample can be seen in borderline personality disorder, is effective in occurrence of different harmful behaviors. Adherence to religion and doing rites will limit people's free time (e.g. five prayers per day) and contributes to self-control (e.g. in a fasting month) and self-organization (timely prayers), which in turn reduces the possibility for risky behavior and those caused by impulses. Quran says "Indeed, prayer prohibits immorality and wrongdoing" (Surah Al-Ankabut, verse 45).

Looking at the civilization history and the available theories in this area, it can be supposed how human life would be at risk by doing risky behaviors, if the social and individual life regulations, with its most traditional forms as religion, did not exist in primitive communities.

\section{References}

1. Lester D. Spirituality and religiosity as predictors of depression and suicidal ideation: an exploratory study. Psychol Rep. 2012;110(1):247-50.

2. Amit BH, Krivoy A, Mansbach-Kleinfeld I, Zalsman G, Ponizovsky $\mathrm{AM}$, Hoshen M, et al. Religiosity is a protective factor against selfinjurious thoughts and behaviors in Jewish adolescents: Findings from a nationally representative survey. Eur Psychiatry. 2014.
3. Sinha JW, Cnaan RA, Gelles RJ. Adolescent risk behaviors and religion: findings from a national study. J Adolesc. 2007;30(2):231-49.

4. Steinman KJ, Zimmerman MA. Religious activity and risk behavior among African American adolescents: concurrent and developmental effects. Am J Community Psychol. 2004;33(3-4):151-61.

5. Nonnemaker JM, McNeely CA, Blum RW. Public and private domains of religiosity and adolescent health risk behaviors: evidence from the National Longitudinal Study of Adolescent Health. Soc Sci Med. 2003;57(11):2049-54.

6. Pardini DA, Loeber R, Farrington DP, Stouthamer-Loeber M. Identifying direct protective factors for nonviolence. Am J Prev Med. 2012;43(2 Suppl 1):S28-40.

7. Dowshen N, Forke CM, Johnson AK, Kuhns LM, Rubin D, Garofalo R. Religiosity as a protective factor against HIV risk among young transgender women. J Adolesc Health. 2011;48(4):410-4.

8. Fatusi AO, Blum RW. Predictors of early sexual initiation among a nationally representative sample of Nigerian adolescents. BMC Public Health. 2008;8:136.

9. Ronneberg CR, Miller EA, Dugan E, Porell F. The Protective Effects of Religiosity on Depression: A 2-Year Prospective Study. Gerontologist. 2014.

10. Greening L, Stoppelbein L. Religiosity, attributional style, and social support as psychosocial buffers for African American and white adolescents' perceived risk for suicide. Suicide Life Threat Behav. 2002;32(4):404-17.

11. Klanjsek R, Vazsonyi AT, Trejos-Castillo E. Religious orientation, low self-control, and deviance: Muslims, Catholics, Eastern Orthodox-, and "Bible Belt" Christians. J Adolesc. 2012;35(3):671-82.

12. Yonker JE, Schnabelrauch CA, Dehaan LG. The relationship between spirituality and religiosity on psychological outcomes in adolescents and emerging adults: a meta-analytic review. J Adolesc. 2012;35(2):299-314.

13. Mojahed A, Kalantari M, Molavi H, Taher-Neshatdoost H, Bakhshani NM. Comparison of Islamic oriented and classical Cognitive Behavioral Therapy on mental health of martyrs' and veterans' wives.J Fundamentals of Mental Health. 2010;11(4):282-91.

14. Rajaee A, Bayazi MH, Habibipour H. Basic Religious Beliefs, Identity Crisis, and General Health in Young Adults. Develop Psychol. 2010;6(22):97-107. 